Gut, 1962, 3, 42

\title{
Excretion of formimino-glutamic acid in steatorrhoea
}

\author{
J. P. KNOWLES ${ }^{1}$ \\ From the Medical Unit, University College Hospital, London
}

SYNOPSIS Minor degrees of folic acid deficiency are very common in idiopathic steatorrhoea. The urinary excretion of formimino-glutamic acid (Figlu) after a histadine load is a satisfactory means of detecting this deficiency and may be used as a screening test for idiopathic steatorrhoea.

The absorption of folic acid is frequently impaired in those cases of steatorrhoea in which there is a histological abnormality of the mucosa of the small intestine whereas if the mucosa is normal absorption is usually unimpaired. Table I shows the results of folic acid absorption tests carried out by three groups of authors in various types of steatorrhoea. It will be seen that in idiopathic steatorrhoea, in which the intestinal mucosa is usually abnormal, folic acid absorption is frequently impaired, whereas in postgastrectomy steatorrhoea and pancreatic steatorrhoea, in which the intestinal mucosa is either normal or shows minimal changes (Badenoch, Evans, Richards, and Witts, 1955; Doniach and Shiner, 1957; Baird and Dodge, 1957; and Joske and Blackwell, 1959), folic acid absorption is usually normal. In Crohn's disease Cox, Meynell, Cooke, and Gaddie (1958) suggested that malabsorption was most frequent in those cases in which the disease process affected the jejunum, postulating this as the site of folic acid absorption, and the fact that absorption is normal in the majority of cases is in keeping with the observation that this disease more frequently affects the more distal part of the small intestine.

Anderson, Belcher, Chanarin, and Mollin (1960)

${ }^{1}$ Working with a grant from the Medical Research Council. have studied folic acid absorption more directly with the aid of radioactive folic acid labelled with tritium. In idiopathic steatorrhoea 'normal absorption' was found in four out of 13 cases when faecal excretion was measured and two of these four cases were also within normal limits when urinary excretion was measured. On the other hand, folic acid absorption was estimated by the microbiological method of Chanarin, Anderson, and Mollin (1958a) in three of these four patients and was abnormal in all three. It is suggested that this discrepancy may be due to the rate of absorption being slow (as measured by the microbiological method utilizing blood levels) even though the total absorption may be normal (as measured by the radioactive method).

Other tests have been directed at measuring the tissue stores of folic acid, which might be expected to reflect the efficiency of absorption.

Direct measurement of the tissue stores in life is not yet possible, though Girdwood (1952) has attempted this on post-mortem and liver biopsy material. Indirect tests measuring folic acid stores include the folic acid clearance test of Chanarin et al. (1958b), in which the rate of clearance of folic acid from the plasma is measured and found to be faster in patients with folic acid deficiency. However, this test is really measuring folic acid turnover which is

TABLE I

NUMBER OF PATIENTS WITH ABNORMAL FOLIC ACID ABSORPTION TEST RESULTS AS DETERMINED BY VARIOUS AUTHORS

\begin{tabular}{lcccc} 
& $\begin{array}{l}\text { Idiopathic } \\
\text { Steatorrhoea }\end{array}$ & $\begin{array}{l}\text { Post-gastrectomy } \\
\text { Steatorrhoea }\end{array}$ & $\begin{array}{c}\text { Pancreatic } \\
\text { Steatorrhoea }\end{array}$ & Crohn's Disease \\
\hline Doig and Girdwood (1960) & $25(30)^{1}$ & $0(20)$ & - & $1(2)$ \\
Cox et al. (1958) & $24(26)$ & $1(6)$ & $0(12)$ & $6(22)$ \\
Chanarin et al. (1958a) & $18(20)$ & $1(3)$ & $0(3)$ & $7(27)$
\end{tabular}

${ }^{1}$ Figure in brackets is total number of patients studied. 
likely to be abnormal when the demand for folic acid is increased by hyperactivity of the bone marrow, and there need not necessarily be any deficiency of folic acid. There is little information available on clearance of folic acid in steatorrhoea; Chanarin et al. (1958b) found normal clearances in two out of six patients.

A more promising test is the measurement of the fasting serum folic acid level analogous to measuring the serum vitamin $B_{12}$ level. Until recently methods were insufficiently sensitive to detect folic acid in the sera of all normal subjects but Herbert (1959) and Baker, Herbert, Frank, Pasher, Hutner, Wasserman, and Sobotka (1959) have recently evolved a more sensitive method. To date this work has not been confirmed by other workers (Luhby and Cooperman, 1960).

The detection of an abnormal excretion of formimino-glutamic acid (Figlu) after a histidine test load seems to be a reliable, though indirect, measurement of the folic acid stores (Bakerman, Silverman, and Daft, 1951; Tabor, Silverman, Mehler, Daft, and Bauer, 1953) and we have recently summarized the theoretical basis of the test and introduced a simplified method for the detection of Figlu (Knowles, Prankerd, and Westall, 1960). Briefly, the test depends on the inability of the body to metabolise histidine fully in the absence of folic acid. Figlu is a degradation product of histidine metabolism which is normally broken down to glutamic acid, but if folic acid is deficient this reaction is impeded and Figlu accumulates in the body and is excreted in the urine.

The excretion of Figlu in 44 cases of steatorrhoea has been studied and the results are reported here, using and comparing several different methods of detecting Figlu.

\section{MATERIAL}

Forty-four patients were studied. Clinical details and laboratory investigations are listed in Tables II and III. An attempt was made to do histidine tests on all those patients admitted to University College Hospital between May 1960 and January 1961 who were being investigated for steatorrhoea. All patients who had an abnormal fat balance were tested except one. Five patients (Cases 5 and 30 to 33) under the care of Dr. J. R. Nassim at the Royal National Orthopaedic Hospital, Stanmore, three patients under the care of Dr. F. Avery Jones at the Central Middlesex Hospital (Cases 23 to 25), and another patient (Case 20) under the care of Dr. J. H. Walters at Queen Mary's Hospital, Roehampton, were also studied.

\section{METHODS}

DETECTION OF FIGLU BY HIGH-VOLTAGE ELECTROPHORESIS (KNOWLES et al., 1960) We have modified the method of performing the histidine test in several details. A single urine collection is now made for six hours after a $20 \mathrm{~g}$. histidine load, and we have increased the strength of our acetone acetic acid mixture from $23 / 2$ to $20 / 5(\mathrm{v} / \mathrm{v}$ ).

DETECTION OF FIGLU BY PAPER CHROMATOGRAPHY Onedimensional ascending runs using 25-200 $\mu \mathrm{l}$. of urine were made on Whatman No. 1 paper as suggested by Luhby, Cooperman, and Teller (1959a) using t-butanol $75 \%$, formic acid $15 \%$, and water $15 \%$ (Block, 1950) as a solvent. A few runs were made in two dimensions using water-saturated phenol as the second solvent.

DETECTION OF FIGLU USING LOW-VOLTAGE ELECTROPHORESIS 1 Using Whatman No. 1 paper in the apparatus described by Flynn and de Mayo (1951), $10 \mu \mathrm{l}$. of urine was placed on the strips which were then run at $120 \mathrm{v}$. and 2 milliamp. for seven hours.

2 Using cellulose-acetate paper as described by Kohn (1960), 5-10 $\mu$ l. of urine was placed on the strips which were then run at $200 \mathrm{v}$. and 6-8 milliamp. for 30 minutes or two hours.

The buffer used was the same as that previously described for the high-voltage technique (Knowles et al., 1960), and the staining procedure was also the same, except that, as acetone cannot be used in treating cellulose acetate, alcoholic solvents were used.

In all the above methods duplicate strips were run of all urines, and one of these strips was treated with ammonia before reacting with ninhydrin. Ninhydrin reacts with all compounds with a free amino group, but Figlu has no free amino group and treatment with alkali is required to release the formimino group and free the amino group, thus allowing it to react. Markers were always run with each strip.

Vitamin $\mathbf{B}_{12}$ was assayed by Dr. Peter Sewell using Lactobacillus leishmannii as test organism. Dr. Margot Shiner kindly undertook biopsy of the small intestine in Cases 11, 12, 20, and 27 and Dr. David Edwards did biopsies in Cases 4 and 10. Biopsies in Cases 2 and 8 were done at laparotomy, and in Case $\mathbf{4 0}$ material was obtained at necropsy.

\section{COMPARISON OF METHODS}

HIGH-VOLTAGE ELECTROPHORESIS Apart from the tests reported here experience has been gained of over 400 tests in approximately 200 patients, and the method is satisfactory in differentiating patients into two groups: (1) normal, with no excess of Figlu detected, and (2) abnormal, with a definite excess of Figlu. Almost all patients who have had an abnormal test have had a disease in which folic acid deficiency might be expected to occur. There have been two exceptions: two elderly women left hospital before investigations could be completed. It seemed possible that both might be suffering from dietary deficiency of folic acid but steatorrhoea was not excluded in either. When folic acid has been administered the test has been normal always. Five to $10 \%$ of patients with iron-deficiency anaemia have an 
TABLE II

PATIENTS WITH STEATORRHOEA AND ABNORMAL EXCRETION OF FIGLU

\begin{tabular}{|c|c|c|c|c|c|c|c|c|c|}
\hline $\begin{array}{l}\text { Case } \\
\text { No. }\end{array}$ & $\begin{array}{l}\text { Age } \\
\text { and } \\
\text { Sex }\end{array}$ & $\begin{array}{l}H b \\
(\mathrm{~g} . \%)\end{array}$ & $\begin{array}{l}\text { M.C.V. } \\
(\mu 3)\end{array}$ & $\begin{array}{l}\text { M.C.H.C. } \\
(\mathrm{g} . \%)\end{array}$ & $\begin{array}{l}\text { Bone } \\
\text { Marrow }\end{array}$ & $\begin{array}{l}\text { Serum } \\
\text { B12 } \\
(\mu \mu \mathrm{g} . / \mathrm{ml} .)\end{array}$ & $\begin{array}{l}\text { Faecal } \\
\text { Fat } \\
\text { (g./day) }\end{array}$ & $\begin{array}{l}\text { Intestinal } \\
\text { Biopsy }\end{array}$ & $\begin{array}{l}\text { Excretion Comments } \\
\text { of Figlu } \\
\text { (mg./hr. in } \\
\text { first } 6 \mathrm{hr} .)\end{array}$ \\
\hline
\end{tabular}

Diagnosis

\begin{tabular}{|c|c|c|c|c|c|c|c|c|c|c|c|}
\hline 1(RE) & $42 \mathrm{M}$ & $12 \cdot 1$ & 92 & 29 & Normal & 240 & $18 \cdot 3$ & - & $36 \cdot 0$ & $\begin{array}{l}\text { Good response to gluten- } \\
\text { free diet }\end{array}$ & I.S. \\
\hline 2(DG) & $14 M$ & $14 \cdot 8$ & - & - & - & - & $31 \cdot 0$ & $\begin{array}{l}\text { Atrophic } \\
\text { mucosa }\end{array}$ & $3 \cdot 0^{+,++}$ & $\begin{array}{l}\text { Presented with iron de- } \\
\text { ficiency }(\mathrm{Hb}=7.4 \mathrm{~g} . \%) \\
\text { Histidine test done after } \\
\text { therapy with iron }\end{array}$ & I.S. \\
\hline 3(KD) & $42 \mathrm{~F}$ & $7 \cdot 2$ & 150 & 30 & $\begin{array}{l}\text { Megaloblastic } \\
\text { haematopoiesis }\end{array}$ & - & $9 \cdot 8$ & - & $16 \cdot 0$ & $\begin{array}{l}\text { Good response to gluten- } \\
\text { free diet }\end{array}$ & I.S. \\
\hline $4(E Y)$ & $56 \mathrm{M}$ & $13 \cdot 2$ & 80 & 34 & - & 50 & $14 \cdot 3$ & $\begin{array}{l}\text { Atrophic } \\
\text { mucosa }\end{array}$ & $7 \cdot 2$ & Life-long diarrhoea & I.S \\
\hline S(UD) & $50 \mathrm{~F}$ & $9 \cdot 0$ & - & 27 & - & - & $18 \cdot 0$ & - & 94.0 & $\begin{array}{l}\text { Good response to gluten- } \\
\text { free diet }\end{array}$ & I.S. \\
\hline $6(A B)$ & $23 \mathrm{M}$ & 13.9 & - & - & - & - & $22 \cdot 0$ & - & $24 \cdot 5$ & $\begin{array}{l}\text { Good response to gluten- } \\
\text { free diet }\end{array}$ & I.S. \\
\hline $7(L L)$ & $51 \mathrm{M}$ & $14 \cdot 1$ & 107 & 31 & Normal & - & $29 \cdot 6$ & - & 4.0 & $\begin{array}{l}\text { Good response to gluten- } \\
\text { free diet }\end{array}$ & I.S. \\
\hline $8(G T)$ & $49 M$ & $15 \cdot 1$ & - & - & - & - & $46 \cdot 6$ & $\begin{array}{l}\text { Meckel's } \\
\text { diverticulum } \\
\text { normal }\end{array}$ & $2 \cdot 1^{1+}$ & $\begin{array}{l}\text { Life-long diarrhoea His- } \\
\text { tidine test done after } 1 \\
\text { year on not very strict } \\
\text { gluten-free diet. Recently } \\
\text { good response to strict } \\
\text { gluten-free diet }\end{array}$ & I.S. \\
\hline 9(HK) & $50 \mathrm{~F}$ & $14 \cdot 7$ & - & - & - & 275 & $12 \cdot 2$ & - & $66 \cdot 5$ & $\begin{array}{l}\text { Good response to gluten- } \\
\text { free diet }\end{array}$ & I.S. \\
\hline 10(AC) & $32 \mathrm{~F}$ & $14 \cdot 8$ & - & - & - & 265 & $8 \cdot 3$ & $\begin{array}{l}\text { Atrophic } \\
\text { mucosa }\end{array}$ & $6 \cdot 7$ & $\begin{array}{l}\text { Just starting gluten-free } \\
\text { diet }\end{array}$ & I.S. \\
\hline 11(DC) & $2 \frac{1}{2} F$ & $10 \cdot 0$ & 89 & 33 & - & 440 & $4 \cdot 3$ & $\begin{array}{l}\text { Atrophic } \\
\text { mucosa }\end{array}$ & $14 \cdot 5$ & $\begin{array}{l}\text { Just starting gluten-free } \\
\text { diet }\end{array}$ & I.S. \\
\hline $12(\mathrm{SL})$ & $13 \mathrm{~F}$ & $15 \cdot 0$ & - & - & - & - & $16 \cdot 3$ & $\begin{array}{l}\text { Atrophic } \\
\text { mucosa }\end{array}$ & $6 \cdot 3$ & $\begin{array}{l}\text { Just starting gluten-free } \\
\text { diet }\end{array}$ & I.S. \\
\hline 13(OW) & $63 \mathrm{~F}$ & $14 \cdot 0$ & 105 & 35 & - & - & $7 \cdot 6$ & - & $7 \cdot 0^{++}$ & $\begin{array}{l}\text { Life-long diarrhoea Osteo- } \\
\text { malacia Just starting glu- } \\
\text { ten-free diet }\end{array}$ & ?I.S. \\
\hline 14(SH) & $21 \mathrm{~F}$ & $11 \cdot 5$ & 84 & 32 & - & 315 & $6 \cdot 0$ & - & $33 \cdot 3$ & Life-long diarrhoea & ?I.S. \\
\hline 15(JR) & $84 M$ & $11 \cdot 5$ & 100 & 34 & - & 185 & $10 \cdot 5$ & - & $4 \cdot 3$ & Painless diarrhoea & ?I.S. \\
\hline 16(MD) & $46 \mathrm{~F}$ & $12 \cdot 1$ & 75 & 34 & - & - & $7 \cdot 9$ & - & $2 \cdot 8$ & $\begin{array}{l}\text { No response to gluten- } \\
\text { free diet after one month } \\
\text { Awaiting biopsy }\end{array}$ & ?I.S. \\
\hline $17((\mathrm{MW})$ & $73 F$ & $10 \cdot 1$ & 96 & 32 & - & 一 & $7 \cdot 1$ & - & $13 \cdot 0^{++}$ & Osteomalacia, no diarrhoea & ?I.S. \\
\hline 18(KG) & $50 \mathrm{~F}$ & $21 \cdot 1$ & 118 & 30 & Normal & 80 & $9 \cdot 3$ & - & $16 \cdot 0$ & $\begin{array}{l}\text { Osteomalacia, life-long } \\
\text { diarrhoea }\end{array}$ & ?I.S. \\
\hline 19(CA) & $44 M$ & $3 \cdot 8$ & 130 & 30 & $\begin{array}{l}\text { Megaloblastic } \\
\text { haematopoiesis }\end{array}$ & - & $9 \cdot 1$ & - & $64 \cdot 0$ & $\begin{array}{l}\text { Chronic schizophrenic } \\
\text { Eating highly abnormal } \\
\text { diet }\end{array}$ & ?I.S. \\
\hline 20(SM) & $51 \mathrm{M}$ & $6 \cdot 8$ & 110 & 32 & $\begin{array}{l}\text { Megaloblastic } \\
\text { haematopoiesis }\end{array}$ & & $30 \cdot 0$ & Atypical & $16 \cdot 0$ & $\begin{array}{l}\text { Diarrhoea since active } \\
\text { service in Burma, } 1943 \\
\text { Biopsy unlike either I.S. } \\
\text { or T.S. }\end{array}$ & ?T.S. \\
\hline $21(\mathrm{VC})$ & $53 \mathrm{M}$ & $10 \cdot 8$ & 98 & 35 & Normal & 425 & $18 \cdot 7$ & - & $33 \cdot 3$ & $\begin{array}{l}\text { Laparotomy showed mul- } \\
\text { tiple enlarged glands, bio- } \\
\text { psy of which was incon- } \\
\text { clusive }\end{array}$ & $\begin{array}{l}\text { ?L } \\
\text { ??I.S. }\end{array}$ \\
\hline 22(AS) & $66 \mathrm{M}$ & $13 \cdot 8$ & - & - & - & - & $6 \cdot 8$ & - & $5 \cdot 0$ & & P.G.S. \\
\hline 23(MH) & $39 \mathrm{M}$ & $10 \cdot 6$ & - & 25 & - & - & $25 \cdot 0$ & C.D. & 13.5 & $\begin{array}{l}\text { Crohn's disease of ter- } \\
\text { minal ileum with numerous } \\
\text { strictures and blind loops }\end{array}$ & C.D. \\
\hline 24(CG) & $15 \mathrm{M}$ & $8 \cdot 1$ & - & 28 & - & & $11 \cdot 6$ & - & $6 \cdot 8^{+}$ & $\begin{array}{l}\text { Steatorrhoea complicating } \\
\text { ulcerative colitis }\end{array}$ & I.C. \\
\hline $25(\mathrm{AW})$ & $60 \mathrm{M}$ & 12.5 & - & 30 & Normal & - & $12 \cdot 0$ & C.D. & $120 \cdot 0$ & $\begin{array}{l}\text { Crohn's disease of the } \\
\text { jejunum, } 6 \mathrm{ft} \text {. of jejunum } \\
\text { resected }\end{array}$ & C.D. \\
\hline 26(JR) & $21 \mathrm{~F}$ & $10 \cdot 8$ & 85 & 30 & - & 一 & $5 \cdot 1$ & - & $6 \cdot 7$ & Radiological diagnosis & C.D. \\
\hline
\end{tabular}

I.S. = idiopathic steatorrhoea, T.S. = tropical sprue, $L=1$ ymphoma involving small intestine, P.G.S. = post-gastrectomy steatorrhoea, C.D. = Crohn's disease, I.C. $=$ ileocolitis, ${ }^{+}=$excretion of Figlu measured over first eight hours, ${ }^{++}=$histidine test not done at same time as fat balance. 
TABLE III

PATIENTS WITH STEATORRHOEA AND NORMAL EXCRETION OF FIGLU (LESS THAN 0.5-1.0 MG. PER HOUR) AFTER HISTIDINE

\begin{tabular}{|c|c|c|c|c|c|}
\hline Case No. & $\begin{array}{l}\text { Excretion of } \\
\text { Faecal Fat /Day } \\
(\mathrm{g} .)\end{array}$ & Diagnosis & Case No. & $\begin{array}{l}\text { Excretion of } \\
\text { Faecal Fat/Day } \\
\text { (g.) }\end{array}$ & Diagnosis \\
\hline $\begin{array}{l}27 \\
28 \\
29 \\
30 \\
31 \\
32 \\
33 \\
34 \\
35\end{array}$ & $\begin{array}{r}19.9 \\
13.1 \\
11.1 \\
60.0 \\
15.0 \\
9.0 \\
13.0 \\
8.7 \\
15.0\end{array}$ & $\begin{array}{l}\text { See text } \\
\text { P.G.S. } \\
\text { P.G.S. } \\
\text { P.G.S. } \\
\text { P.G.S. } \\
\text { P.G.S. } \\
\text { P.G.S. } \\
\text { P.G.S. } \\
\text { P.G.S. }\end{array}$ & $\begin{array}{l}36 \\
37 \\
38 \\
39 \\
40 \\
41 \\
42 \\
43 \\
44\end{array}$ & $\begin{array}{l}18 \cdot 0 \\
24 \cdot 3 \\
22.0 \\
1 \\
27 \cdot 6 \\
32 \cdot 0 \\
1 \\
11 \cdot 4 \\
20 \cdot 2\end{array}$ & $\begin{array}{l}\text { P.G.S. } \\
\text { P.G.S. } \\
\text { F.D.P. } \\
\text { F.D.P. } \\
\text { ?L } \\
\text { C.D. } \\
\text { C.D. } \\
\text { C.D. } \\
\text { C.D. }\end{array}$ \\
\hline
\end{tabular}

'Gross clinical steatorrhoea, P.G.S. = post-gastrectomy steatorrhoea, $L=$ lymphoma involving small intestine, F.D.P. = fibrocystic disease of the pancreas, C.D. = Crohn's disease.

abnormal histidine test although they show no evidence of malabsorption.

The amount of Figlu excreted by each patient is shown in Tables II and III. Those patients listed in Table III showed no excess of Figlu.'It should be emphasized again that the method of quantitation used is not exact and gives only approximate results. The technique employed is capable of detecting $2 \cdot 5$ $5.0 \mu \mathrm{g}$. of Figlu per millilitre of urine under optimum conditions whereas in actual practice it is not claimed to be certain of detecting less than 5-10 $\mu \mathrm{g}$. per ml. (approximately $0 \cdot 5-1 \mathrm{mg}$. per hour, assuming a urine flow of $100 \mathrm{ml}$. per hour).

LOW-VOLTAGE ELECTROPHORESIS All the urines tested as above were also studied with low-voltage electrophoresis and paper chromatography.

Cellulose acetate The strip obtained using cellulose acetate was comparable with that obtained with high-voltage electrophoresis. Figlu and glutamic acid were separated well when the strips were run for one and a half to two hours. All those having a Figlu excretion greater than $13.5 \mathrm{mg}$. per hour (approximately 150-300 $\mu \mathrm{g}$. per $\mathrm{ml}$.) showed discernible Figlu spots. Urine containing less Figlu than this could not be distinguished from normal.

When the strip was run for 30 minutes there was no separation of Figlu from glutamic acid, and identification of Figlu depended on an increase in the density of the combined Figlu-glutamic spot after treatment with ammonia. The differences in some of the urines were so slight as to make differentiation from some normal urines not very easy and it was difficult to be confident with any urine containing less than $100 \mu \mathrm{g}$. per $\mathrm{ml}$. It was thus impossible to distinguish from normal 11 patients who had been shown to have abnormal urines by high-voltage electrophoresis. The other 15 were detectable by this method.

Whatman no. 1 filter paper This was quite unsatisfactory. After a run of seven hours Figlu and glutamic acid were not separated, and there had obviously been considerable diffusion by this time, the spots being large. The results were clearly not as good as those obtained using cellulose acetate for half an hour so this method was not pursued further.

PAPER CHROMATOGRAPHY Figlu runs well ahead of histidine, glycine, and glutamic acid in this solvent system but has approximately the same $R_{F}$ value as alanine and threonine. The latter two amino-acids can be separated from Figlu by running in a second solvent system (water-saturated phenol); however, only the results obtained with one-dimensional chromatography will be reported since two-dimensional chromatograms seemed likely to lead to even further loss of sensitivity. Figlu was identified by noting a darkening of the Figlu-alanine-threonine spot after treatment with ammonia.

The presence of Figlu in urine containing less than $500 \mu$ g. per ml. could not be demonstrated with confidence, though some urines containing much less Figlu than this (minimum $=100 \mu \mathrm{g}$. per ml.) were occasionally satisfactory.

\section{PATTERN OF FIGLU EXCRETION}

The pattern of excretion of Figlu was followed in patient No. 9 for 24 hours after a histidine load. Urine was collected hourly for the first 12 hours and subsequently a four-hour and an eight-hour collection were made. After collection the urine specimens were diluted to a volume equivalent to a rate of excretion of $250 \mathrm{ml}$./hour, so that in the resulting electrophoretogram (Fig. 1) the spots have a roughly quantitative relationship one to the other. It will be seen that Figlu begins to appear during the second hour, reaches a peak between five and 10 hours, and is still just discernible during the last eight-hour period.

During the peak excretion time blood samples were taken at six and a half, seven and a half, and 


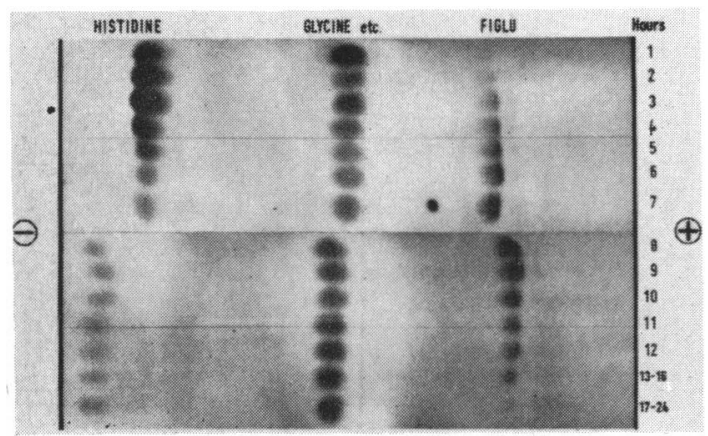

FIG.1. Electrophoretogram after treatment with ammonia and ninhydrin (Case 9). An oral load of 1-histidine was given and urine collected over 24 hours. This was divided into aliquots as indicated. After collection all urine specimens were diluted to give a rate of urine flow equivalent to $250 \mathrm{ml}$. per minute. (Glutamic acid is seen as a small spot just to the right of the Figlu spot.) $+=$ cathode; - = anode.

eight and a half hours, and plasma was separated and ultrafiltered. Figlu could then be detected in the plasma and the concentration was approximately the same in all three specimens of plasma. In the six-, seven-, and eight-hour urine specimens, the concentrations were also approximately equal. It was found that the urine spots had to be diluted 24-32 times to give a spot about equal to that in the plasma. The urine flow during this time was $250 \mathrm{ml}$./minute thus giving an approximate plasma clearance of 96 to $128 \mathrm{ml}$./minute. There was no evidence of renal failure; blood urea was $24 \mathrm{mg}$. $/ 100 \mathrm{ml}$. Using the same methods of quantitation, clearances of histidine and glutamic acid were 4-8 $\mathrm{ml} . /$ minute and $1-2 \mathrm{ml} . /$ minute respectively.

\section{ANALYSIS OF RESULTS IN MALABSORPTION}

Although only a few biopsies have been done it seems reasonable to suggest that the histidine test correlates fairly well with the state of the intestinal mucosa in a similar way to the folic acid absorption tests discussed in the introduction. However, there were exceptions. Patient 22 was the only one of 11 cases of post-gastrectomy steatorrhoea to have an abnormal test result, but unfortunately the state of his intestinal mucosa is not known, whereas patient 27, who had a normal test, had almost complete villous atrophy and the few villi remaining were short and squat. For various reasons he is not thought to be suffering from coeliac disease. He has previously been reported as a case of congenital hypoproteinaemia with aminoaciduria (Bound and Hackett, 1953).
The diagnosis of lymphoma in patients 21 and 40 has not been confirmed histologically, although both had macroscopically abnormal lymph glands. Biopsy of the small intestine was not obtained in patient 21 and in patient 40 it was unsatisfactory due to post-mortem changes. It is possible that both had idiopathic steatorrhoea.

Patients 27 and 40 were the only two patients who might have been suffering from idiopathic steatorrhoea who had normal tests. Both showed many atypical features.

The finding that four out of eight patients with Crohn's disease had normal test results is in keeping with the results of the absorption tests of Cox et al. (1958) and is compatible with the scattered nature of the intestinal lesions in this disease.

Both patients with fibrocystic disease had normal test results which again is in agreement with the normal absorption in all 12 cases of pancreatic steatorrhoea investigated by Cox et al. (1958).

\section{DISCUSSION}

The present work has confirmed that the diagnosis of folic acid deficiency by histidine loading and the detection of Figlu by high-voltage electrophoresis compares well with the more elaborate folic acid absorption tests of other workers shown in Table I, and in particular an equally high proportion of patients had abnormal test results in idiopathic streatorrhoea.

Of the various other methods for detecting Figlu by physical separation, low-voltage electrophoresis using cellulose acetate seems to be the most promising. Using pure Figlu in normal urine the minimum amount detectable is $40-80 \mu \mathrm{g}$. per $\mathrm{ml}$. of urine, but in actual practice it is often difficult to be confident with urine containing less than $100 \mu \mathrm{g}$. per ml. It seems possible that without prior concentration Figlu will not be detected in the urine from some cases which would not be missed by high-voltage electrophoresis. Unfortunately, if urine is too concentrated, streaking occurs both with cellulose acetate and with high-voltage electrophoresis.

From the point of view of detecting Figlu by electrophoresis it is very fortunate that the renal clearance of Figlu is so high and that of glutamic acid is so low. Glutamic acid, like most commonly occurring amino-acids, has a low clearance of less than 2 ml. per minute (Cusworth and Dent, 1960). Normally, the urinary concentration of glutamic acid is low and little or none can be detected after electrophoresis of $25 \mathrm{ml}$. of urine. However, after histidine loading demonstrable quantities are found in the urine and presumably come from the catabolism of histidine and Figlu. The separation of 
amino-acids by electrophoresis depends on their iso-electric point. That of Figlu is only slightly different from that of glutamic acid, and to obtain separation of the two usually requires a run of 10 to 15 minutes using high-voltage electrophoresis $(6,000$ volts) or 90 to 120 minutes using cellulose acetate at low voltage ( 200 volts). When the excretion of Figlu is high the proportion of Figlu to glutamic acid is high and separation of the spots is not necessary to obtain satisfactory results. However, when the excretion is low this ratio is very much reduced and separation of the spots is to be preferred for accurate results.

Paper chromatography has proved less rewarding than cellulose acetate. Luhby et al. (1959a) do not give detailed information about their method which they claim can detect 20-50 $\mu$ g. per ml. of Figlu under favourable conditions. If this were so it would be more sensitive than cellulose acetate $(40-80 \mu$ g. per $\mathrm{ml}$.), but in the present investigation it has not been possible to reproduce this degree of sensitivity.

Figlu can also be determined microbiologically and enzymatically. The advantages and disadvantages of these methods have been discussed previously (Knowles et al., 1960). Using the enzyme method of Tabor and Wyngarden (1958), Luhby et al. (1959b) found the excretion of Figlu after histidine loading to be increased in all 10 cases they studied of 'macrocytic anaemia associated with sprue or malabsorption syndrome'.

The fact that there is a poor correlation between the amount of Figlu excreted and the severity of the steatorrhoea as judged by the M.C.V., haemoglobin, and the daily faecal fat excretion is not necessarily surprising. The blood picture in steatorrhoea is often dimorphic, due to microcytosis secondary to iron deficiency and macrocytosis due to vitamin $\mathbf{B}_{12}$ and folic acid deficiency. The M.C.V. and haemoglobin clearly depend on at least two factors other than folic acid. It is rather more surprising that two of the four heaviest excretors of Figlu should have haemoglobin concentrations greater than $12 \mathrm{~g}$. per $100 \mathrm{ml}$. The daily faecal fat excretion is a measure of the state of the intestine at the time the test is done, whereas the excretion of Figlu is an indirect test of the body stores of folic acid. In general there will be a rough correlation between tests measuring excretion and absorption; it will not necessarily be close.

Malabsorption of folic acid seems to be one of the commonest disorders in idiopathic steatorrhoea. We have recently shown that the body stores of folic acid can be depleted sufficiently to give an abnormal histidine test in four to six weeks (Knowles et al., 1961). It is not surprising, therefore, that this test is frequently abnormal in idiopathic steatorrhoea. For these reasons it offers a simple and effective screening test for idiopathic steatorrhoea, with the added advantage that it can be performed easily on outpatients.

At the moment there is no satisfactory explanation for the occurrence of abnormal histidine tests in a small proportion of patients with iron-deficiency anaemia and post-gastrectomy steatorrhoea, and the problem is under investigation.

\section{SUMMARY}

Minor degrees of folic acid deficiency are very common in idiopathic steatorrhoea. The urinary excretion of Figlu after a histidine load is a satisfactory means of detecting this deficiency and it is suggested that this is the best screening test for idiopathic steatorrhoea. Experience with this test is described.

The currently available methods of detecting Figlu which do not involve enzyme or microbiological assays are described and compared. It is concluded that the method involving high-voltage electrophoresis is the best of these simpler methods, but that low-voltage electrophoresis using cellulose acetate offers a promising alternative. Paper chromatography is laborious by comparison and has not yet been demonstrated to be sufficiently sensitive for practical purposes.

\section{ADDENDUM}

Since submitting this paper for publication experience has been gained on 121 cases of steatorrhoea. Of these, 47 are thought to be suffering from idiopathic steatorrhoea. No further cases of possible idiopathic steatorrhoea with normal histidine tests have been seen since the two mentioned in the text.

I should like to express my thanks to the many physicians who have allowed me to study their cases, and I am especially grateful to Drs. T. A. J. Prankerd and R. G. Westall for their encouragement and advice.

\section{REFERENCES}

Anderson, B., Belcher E. H., Chanarin, I., and Mollin, D. L. (1960). The urinary and faecal excretion of radioactivity after oral doses of ${ }^{3} \mathrm{H}$-folic acid. Brit. J. Haemat., 6, 439.

Badenoch, J., Evans, J. R., Richards, W. C. D., and Witts, L. J. (1955). Megaloblastic anaemia following partial gastrectomy and gastro-enterostomy. Ibid., 1, 339.

Baird, I. McL., and Dodge, O. G. (1957). Jejunal biopsy after partial gastrectomy. Quart. J. Med., 26, 393.

Baker, H., Herbert, V., Frank, O., Pasher, I., Hutner, S. H., Wasserman, L. R. and Sobotka, H. (1959). A microbiologic method for detecting folic acid deficiency in man. Clin. Chem., 5, 275.

Bakerman, H. A., Silverman, M., and Daft, F. S. (1951). Influence of succinylsufathiazole and folic acid on glutamic acid excretion. J. biol. Chem., 188, 117.

Block, R. J. (1950). Estimation of amino acids and amines on paper chromatograms. Analyt. Chem., 22, 1327. 
Bound, J. P., and Hackett, W. R. (1953). Idiopathic hypoproteinaemic oedema and amino-aciduria in an infant. Arch. Dis. Childh. $28,104$.

Chanarin, I., Anderson, B. B., and Mollin, D. L. (1958a). The absorption of folic acid. Brit. J. Haemat., 4, 156.

-, Mollin, D. L., and Anderson, B. B. (1958b). The clearance from the plasma of folic acid injected intravenously in norma subjects and patients with megaloblastic anaemia. Ibid., 4, 435.

Cox, E. V., Meynell, M. J., Cooke, W. T., and Gaddie, R. (1958). The folic acid excretion test in the steatorrhea syndrome. Gastroenterology, 35, 390.

Cusworth, D. C., and Dent, C. E. (1960). Renal clearance of amino acids in normal adults and in patients with aminoaciduria. Biochem. J., 74, 550.

Doig, A., and Girdwood, R. H. (1960). The absorption of folic acid and labelled cyanocobalamin in intestinal malabsorption. Quart. J. Med. 29, 333.

Doniach, I., and Shiner, M. (1957). Duodenal and jejunal biopsies. II. Histology. Gastroenterology, 33, 71.

Flynn, F. V., and de Mayo, P. (1951). Micro-electrophoresis of protein on filter-paper. Lancet, 2, 235.

Girdwood, R. H. (1952). The occurrence of growth factors for Lactobacillus leichmannit, Streptococcus faecalis and Leuconostoc citrovorum in the tissues of pernicious anaemia patients and controls. Biochem. J., $52,58$.

Herbert, V. (1959). The Megaloblastic Anemias, p.85. Grune \& Stratton, New York and London.
Joske, R. A., and Blackwell, J. B. (1959). Alimentary histology in the malabsorption syndrome following partial gastrectomy. Lancet, 2, 379.

Knowles, J. P., Prankerd, T. A. J., and Westall, R. G. (1960). Simplified method for detecting formiminoglutamic acid in urine as a test of folic-acid deficiency. Ibid., $2,347$. Physiol. (Lond.), 157, 24.

Kohn, J. (1960). Cellulose acetate electrophoresis and immuno diffusion techniques. In Chromatographic and Electrophoretic Techniques, ed. Smith, I., Vol. 2, p.56 Heinemann, London.

Luhby, A. L., and Cooperman, J. M. (1960). Formiminoglutamic acid versus serum "folic acid" as an index of folic acid deficiency. J. clin. Invest., 39, 1008.

,-- , and Teller, D. N. (1959a). Urinary excretion of formiminoglutamic acid: Application in diagnosis of clinical folic acid deficiency. Amer, J. clin. Nutr., 7, 397.

$\longrightarrow,-\longrightarrow,(1959 \mathrm{~b})$. Histidine metabolic loading test to distinguish folic acid deficiency from vit. $B_{12}$ in megaloblastic anemias. Proc. Soc. exp. Biol. (N. Y.), 101, 350.

Tabor, H., Silverman, M., Mehler, A. H., Daft, F. S., and Bauer, H. (1953). 1-Histidine conversion to a urinary glutamic acid derivative in folic-deficient rats. J. Amer. chem. Soc., $75,756$.

of formiminoglutamic acid in urine. J. clin. Invest., 37, 824. 